\title{
SINO-US TRADE IMBALANCE
}

\author{
Jiandong Shi ${ }^{1}$
}

DOI: https://doi.org/10.31410/ERAZ.2019.69

\begin{abstract}
The Sino-US trade imbalance has become the most difficult problem of Sino-US bilateral economic relation; it is the blasting fuse of bilateral economic and trade frictions. This current situation results in the large Sino-US bilateral trade statistical gap that leads to the wrong understanding of the scale of bilateral trade imbalance. This article plans to analyze the factors of Sino-US statistical differences from the angle of trade statistics institution under the background of economic globalization. Firstly, it makes a preliminary discussion of relative content of origin rule and analyses the influences of origin rule to the comparability of foreign trade statistics. Thus, further discuss the factors of Sino-US trade imbalance from larger scale and angles to provide beneficial references for studying Sino-US bilateral trade statistical error problems.
\end{abstract}

Keywords: Sino-US trade; trade imbalance; statistical difference; origin rule.

\section{INTRODUCTION}

$\mathrm{W}$ ith the rapid development of Sino-US economic and trade relations, trade imbalance is increasingly prominent and has become the important factor that influences the further development of Sino-US economic and trade relations. According to the US statistical material, China has replaced Japan and become the first trade deficit country of the US since 2000. According to China's Ministry of Commerce, China's trade surplus to the US reached 114.17 billion dollars in 2005, which increased 33.9 billion dollars than 2004; trade deficit of the US in 2007 to China was 256.2 dollars, which accounted for $27 \%$ of the total foreign trade deficit of the US and close to the total foreign trade deficit of the US to the Europe and Japan; the trade surplus of China to the US in 2008 was sustainable grow to 163.33 billion dollars again. The Sino-US trade unbalanced issue was raising concerns among all circles in the US. Some people of the US even attribute trade unbalance to the RMB exchange rate issue and some people think China carry out mercantilism, foster export and limit import and China should be responsible for that, so they ceaselessly clamp down China in RMB exchange rate, anti-dumping and intellectual property, which results in increasingly bilateral trade friction and conflict. While according to China, the bilateral trade unbalances scale of China and the US is far less than the statistical result of the US and the main causes are not the above reasons, the difference of bilateral trade statistical data is the critical reason that amplifies the Sino-US trade unbalance among them. The dispute of bilateral trade statistical differences between China and the US is a long-standing issue; according to the US, the deficit in commodity trade to China had started in the US since 1983 about 320 million dollars, while according to China's statistical bureau, China had been always trade deficit to the US during the 14 years from 1979 to 1992, then first trade surplus to the US since 1993 about 6.3 billion dollars; in this year, according to the data of the US Department of Commerce, the trade deficit between China and the US is as high as 22.786 billion dollars. There had been dispute when China started trade surplus to the US between China and the US. The statistical difference directly influences the judgment of bilateral trade surplus scale of China and the US. In that way, how the situation of Sino-US trade unbalance

National University of Public Service, H-1083 Budapest, 2 Ludovika tér, Hungary 
on earth? How big is trade gap between China and the US? In order to maintain the healthy and good development of Sino-US economic and trade relations, it is necessary to find the real factors that result in bilateral statistical differences, restore the reality of trade unbalance between China and the US and strive to seek for the solutions of solving the bilateral trade unbalance.

\section{RULE OF ORIGIN}

Rule of origin refers to the universally applicable laws, rules and administrative decisions of one country or area to confirm the origin country of commodity; the core is to determine the specific standards of commodity that is origin criterion. According to Agreement on Rules of Origin, the specific implement standards include: 1. Change Criterion of Tariff Classification, also known as Change Standard of Tax Item Number, which refers to that after processed and manufactured, the tax items classification number of all raw materials of the product is different from the tax items classification number of the finished product, then the processing and manufacturing place is the origin place; 2 . Ad valorem percentage criterion confirms the origin place of the product according to the proportional relation between import part or inland part of the product and the value itself; 3 . specific processing standard is formulated according to the manufacturing procedure of the product. $^{2}$

The origin criterion is the most suitable standard that accord with principle of cross-border flow of material resources confirmed by Concepts and Definitions of International Trade Statistics, so now governments adopts the origin country criterion to confirm the source of commodity. Rule of origin directly decided the comparability of every country's foreign trade statistics. But there are differences in origin rule among countries that result in the huge gap of bilateral trade statistics. On the other hand, the trade statistical system based on regional statistical rules cannot reflect current international trade pattern and real trade balance situation when foreign capital and processing trade has more effect in foreign trade. Then current trade statistical systems face challenge. ${ }^{3}$

\section{TAKE PROCESSING TRADE AS EXAMPLE TO ANALYZE THE EFFECT OF ORIGIN RULE ON SI-NO TRADE STATISTICAL GAP}

\subsection{China's export situation of procession trade}

Processing Trade is a kind of trade that emerging with increasingly deepens international division of labor under economic globalization, which firstly derived from Euromerican clothing industry in the $1960 \mathrm{~s}^{4}$

However, the definition of processing trade has not been cleared and unified yet. Generally, processing trade refers to the trade form that exported after imported raw material, accessories and assembling improved parts from foreign countries.

In the past three decades, implementing processing trade was the important part of China's opening up strategy and a now road of China to boost industrialization. The processing trade featured by "large-volume import and export and put both ends of the production process on the

Huaiqin Jia. (2004). A Summary of Sino-US Trade Balance Issues, University of International Business and Economics Press in China.P16-19

3 Huaiqin Jia. (1992).Comparability of Rules of Origin and Foreign Trade Statistics, International Trade Issues, No. 11, P9-21

$4 \quad$ Xiangshuo Yin. (2001) International Trade Course, Fudan University Press, P26-30 
world market" occupied half of the country. China's export of high capital-intensive and hightech product was still taking processing trade as the main part, more than $75 \%$ of high-tech export come from processing imported materials trade, more than 10\% of that from processing supplied materials trade. General trade took few proportions (Junyan Qi, 2008). Tablel shows that over half of export value of China's foreign trade comes from processing trade. China's total export is 62.1 billion dollars in 1990 and processing trade export is 25.42 billion dollars; the total trade in 2007 is 1218.02 billion dollars and processing trade export is 617.56 billion dollars; the proportion of processing trade account for total trade raise increasingly, while even more than $60 \%$ to the export of the US. So, to speak that processing trade export is a main method of China's foreign trade export growth. While under the processing trade, a country's export includes a large number of imports, there is specific overrate of China's export scale under the current trade statistical method. In view of this, combine China's trade practical activity is necessary to research the effect of processing trade on Sino-US trade statistic.

\subsection{The effect of processing trade on Si-no-US trade gap statistics}

Firstly, Chinese current origin rule has so low requirements for origin criterion formulation, especially lack of unified specific standard for the origin of product assembling that has specific subjective color and randomness when issuing certificate of origin. Therefore, foreign merchant tries every means to acquire the "certificate of China's origin" by buying China's primary product or semi-finished product, then export with "made in China" after processed the origin product. While importing country would regard it as "Chinese product" as long as see the label of "made in China", these products not only seize the special preferential treatment that real Chinese made products enjoyed, but also watered China's export trade volume. Combined with the above graph, the processing trade of foreign enterprises is higher than domestic enterprises from the beginning to the end that verified China's processing trade export that was pushed by foreign-owned enterprises. Under the mode of processing trade, China's effective yield only include lower processing charges, while assumed all negative effects brought by trade surplus result in frequent anti-dumping and special protection on China from other countries, which directly influenced the trade export that real belonged to China. The benefits pattern generated by processing trade was warped in the trade statistics that take origin country as its core, it not only exaggerated the scale of Sino-US trade unbalance, but also cover and vague the relation of benefits distribution under international production arrangement.

Secondly, processing trade not only take high proportion on total trade, the price raising of middleman, but also result in that import declaration price of the US is higher than Chinese export declaration price. Namely, Chinese enterprises import raw material, spare and accessory parts and packing materials from foreign countries, then export them to the US after processed or fitted. Chinese processing enterprises always accept an order by middleman then resell the processed product to the buyer of the US. Therefore, Chinese export declaration price often is the lower price when the middleman bought, while the price to the buyer of the US is often raised by middleman. However, both China and the US don't have enough information to identify the commodity of direct trade that were bought and respelled by middleman in bilateral trade statistics. So, it is hard to exclude the influence of procession trade on Sino-US bilateral trade statistics in Sino-US trade statistics.

In a word, China's export trade developed gradually by introducing FDI and developing processing trade under the background of increasingly deepened international intra-production specialization and gradually formed global value chain. So, to speak that processing trade is a 
try of seeking new industrialization road under economic globalization, the positive effect on China's economic development should be comprehended under the cover of participating in the international division of labor. However, processing trade should be excluded out of trade statistics and consider import for the export including import content.

Table 1. Export Situation of China’s improvement trade. Unit: \$100 million.

\begin{tabular}{|c|c|c|c|}
\hline Years & $\begin{array}{c}\text { Export volume } \\
\text { of improvement trade }\end{array}$ & Total export volume & $\begin{array}{c}\text { The proportion } \\
\text { of improvement trade } \\
\text { in total exports (\%) }\end{array}$ \\
\hline 1993 & 442.48 & 917.40 & 48.23 \\
\hline 1994 & 569.80 & 1210.10 & 47.09 \\
\hline 1995 & 737.03 & 1487.80 & 49.54 \\
\hline 1996 & 843.34 & 1510.50 & 55.83 \\
\hline 1997 & 996.02 & 1827.90 & 54.49 \\
\hline 1998 & 1044.71 & 1837.10 & 56.87 \\
\hline 1999 & 1108.72 & 1949.30 & 56.88 \\
\hline 2000 & 1376.52 & 2492.00 & 55.24 \\
\hline 2001 & 1474.33 & 2661.00 & 55.2 \\
\hline 2002 & 1799.28 & 3256.00 & 55.4 \\
\hline 2003 & 2418.51 & 4382.75 & 55.3 \\
\hline 2004 & 3279.70 & 5933.60 & 55.2 \\
\hline 2005 & 4164.67 & 7620.00 & 55.3 \\
\hline 2006 & 5103.55 & 9690.80 & 56.9 \\
\hline 2007 & 5175.60 & 12180.20 & 50.71 \\
\hline
\end{tabular}

Source: Xiaochao Li. (2008). China Statistical Yearbook, China Statistical Publishing House, P721-723

Table 2. the proportion of improvement trade exports of domestic enterprises in China (\%)

\begin{tabular}{|c|c|c|c|c|c|c|c|c|c|}
\hline \multirow[t]{3}{*}{ Years } & \multicolumn{3}{|c|}{ All domestic enterprises } & \multicolumn{3}{|c|}{ State-owned enterprise } & \multicolumn{3}{|c|}{ Private enterprise } \\
\hline & \multirow{2}{*}{$\begin{array}{l}\text { Improve- } \\
\text { ment } \\
\text { trade }(\%)\end{array}$} & \multicolumn{2}{|c|}{$\begin{array}{l}\text { Among them (ac- } \\
\text { counted for } \%)\end{array}$} & \multirow{2}{*}{$\begin{array}{l}\text { Improve- } \\
\text { ment } \\
\text { trade }(\%)\end{array}$} & \multicolumn{2}{|c|}{$\begin{array}{l}\text { Among them (ac- } \\
\text { counted for } \% \text { ) }\end{array}$} & \multirow{2}{*}{$\begin{array}{l}\text { Improve- } \\
\text { ment } \\
\text { trade }(\%)\end{array}$} & \multicolumn{2}{|c|}{$\begin{array}{l}\text { Among them (ac- } \\
\text { counted for } \% \text { ) }\end{array}$} \\
\hline & & $\begin{array}{l}\text { Process- } \\
\text { ing with } \\
\text { custom- } \\
\text { er's ma- } \\
\text { terials }\end{array}$ & $\begin{array}{l}\text { Process- } \\
\text { ing with } \\
\text { imported } \\
\text { materials }\end{array}$ & & $\begin{array}{l}\text { Process- } \\
\text { ing with } \\
\text { custom- } \\
\text { er's ma- } \\
\text { terials }\end{array}$ & $\begin{array}{l}\text { Process- } \\
\text { ing with } \\
\text { imported } \\
\text { materials }\end{array}$ & & $\begin{array}{l}\text { Process- } \\
\text { ing with } \\
\text { custom- } \\
\text { er's ma- } \\
\text { terials }\end{array}$ & $\begin{array}{l}\text { Process- } \\
\text { ing with } \\
\text { imported } \\
\text { materials }\end{array}$ \\
\hline 1995 & 31.06 & 56.2 & 43.8 & 35.88 & 56.26 & 43.74 & 35.88 & 54.13 & 45.87 \\
\hline 1996 & 34.88 & 63.21 & 36.79 & 37.81 & 63.55 & 36.55 & 37.81 & 55.56 & 44.44 \\
\hline 1997 & 33.21 & 65.1 & 34.9 & 34.14 & 65.56 & 34.44 & 34.14 & 56.19 & 43.81 \\
\hline 1998 & 34.33 & 66.61 & 33.39 & 32.49 & 67.42 & 32.58 & 32.49 & 52.78 & 47.22 \\
\hline 1999 & 34.18 & 69.89 & 30.11 & 29.54 & 71.23 & 28.77 & 29.54 & 50.05 & 49.95 \\
\hline 2000 & 31.15 & 69.25 & 30.75 & 26.14 & 71.78 & 28.22 & 26.14 & 42.34 & 57.66 \\
\hline 2001 & 30.74 & 68.26 & 31.74 & 25.17 & 72.31 & 27.69 & 25.17 & 38.89 & 61.11 \\
\hline 2002 & 29.13 & 68.02 & 31.98 & 19.66 & 72.76 & 27.24 & 19.66 & 39.42 & 60.58 \\
\hline 2003 & 26.05 & 64.52 & 35.48 & 20.17 & 68.85 & 31.15 & 20.17 & 50.41 & 49.59 \\
\hline 2004 & 24.19 & 62.68 & 37.32 & 17.31 & 68.54 & 31.46 & 17.31 & 47.9 & 52.1 \\
\hline 2005 & 21.98 & 57.67 & 42.33 & 15.42 & 64.15 & 35.85 & 15.42 & 44.43 & 55.57 \\
\hline 2006 & 19.55 & 52.69 & 47.31 & 12.99 & 59.16 & 40.84 & 12.99 & 40.71 & 59.29 \\
\hline 2007 & 18.41 & 51.5 & 48.5 & 12.24 & 59.17 & 40.83 & 12.24 & 38.91 & 61.09 \\
\hline 2008 & 16.14 & 49.43 & 50.57 & 11.18 & 56.38 & 43.62 & 11.18 & 32.92 & 67.08 \\
\hline
\end{tabular}

Source: Xiaochao Li. (2008). China Statistical Yearbook, China Statistical Publishing House, P721-723 
Table 3. the proportion of processing trade exports of foreign-funded enterprises in China (\%)

\begin{tabular}{|c|c|c|c|c|c|c|}
\hline \multirow{2}{*}{ Years } & \multicolumn{3}{|c|}{ Sino-foreign joint ventures } & \multicolumn{3}{c|}{ Wholly foreign-owned enterprise } \\
\cline { 2 - 7 } & $\begin{array}{c}\text { Improvement } \\
\text { trade (\%) }\end{array}$ & $\begin{array}{c}\text { Processing } \\
\text { with custom- } \\
\text { er's materials } \\
(\%)\end{array}$ & $\begin{array}{c}\text { Processing } \\
\text { with imported } \\
\text { materials (\%) }\end{array}$ & $\begin{array}{c}\text { Improvement } \\
\text { trade (\%) }\end{array}$ & $\begin{array}{c}\text { Processing } \\
\text { with custom- } \\
\text { er's materials } \\
(\%)\end{array}$ & $\begin{array}{c}\text { Processing } \\
\text { with imported } \\
\text { materials (\%) }\end{array}$ \\
\hline 1995 & 85.0 & 8.81 & 91.19 & 94.02 & 4.56 & 95.44 \\
\hline 1996 & 80.21 & 10.97 & 89.03 & 92.22 & 6.18 & 93.82 \\
\hline 1997 & 78.56 & 12.35 & 87.65 & 91.84 & 7.42 & 92.58 \\
\hline 1998 & 77.89 & 12.56 & 87.44 & 91.83 & 9.04 & 90.96 \\
\hline 1999 & 75.56 & 14.83 & 85.17 & 91.11 & 12.8 & 87.2 \\
\hline 2000 & 73.23 & 13.62 & 86.38 & 88.03 & 12.61 & 87.39 \\
\hline 2001 & 71.74 & 12.63 & 87.37 & 86.77 & 12.97 & 87.03 \\
\hline 2002 & 69.40 & 10.72 & 89.28 & 86.08 & 12.22 & 87.78 \\
\hline 2003 & 68.21 & 41.12 & 58.88 & 85.84 & 12.22 & 31.15 \\
\hline 2004 & 66.77 & 7.87 & 92.13 & 85.21 & 12.18 & 87.83 \\
\hline 2005 & 64.94 & 7.44 & 92.56 & 84.56 & 14.31 & 85.69 \\
\hline 2006 & 60.82 & 7.92 & 92.08 & 83.46 & 13.51 & 86.49 \\
\hline 2007 & 59.11 & 7.88 & 92.12 & 81.89 & 13.86 & 86.14 \\
\hline 2008 & 55.84 & 7.15 & 92.85 & 79.59 & 10.06 & 89.34 \\
\hline
\end{tabular}

Source: Xiaochao Li. (2008). China Statistical Yearbook, China Statistical Publishing House, P721-723

\section{IMPROVEMENT OF FOREIGN TRADE STATISTICS SYSTEM}

\subsection{Analyses on ownership trade statistics system}

Based on above analysis, the trade statistics system based on origin cannot reflect the changed international economic relation and exaggerate the degree of global economic unbalance, while ownership trade statistics system can make up the flaw of the trade statistics system that based on origin well. The trade statistical system based on ownership refers to the statistical system that statistically process the foreign economic activities according to "ownership principle" of asset rather than "origin principle". The current trade statistical system based on origin principle only statistically process the cross-border trade volume, and cannot really reflect the trade benefits of the country, while the trade statistical system based on ownership based on origin statistics and whether the commodity ownership based on cross-border transformation among the citizen, added the statistics of "cross border" rather than "cross citizen" and the business activities of "cross citizen" rather than "cross border", which directly confirmed the clear relation between FDI and trade, and the trade statistical system of ownership principle can easily overcome the double counting problem of intermediate goods trade of international production network if it excluded the payment of foreign merchant's investment in the subsidiary corporation of the host country and the input cost of labor force and capital on the host country from sales revenue; for example, "ownership principle" can avoid the double counting of "origin principle" when the intermediate product of final product forming process flowing in transnational corporation during transnational corporations is allocating the factor input in the world. Therefore, it is more scientific and perfect than traditional trade statistical system.

More precisely, compared with origin trade statistics, ownership trade statistical system includes the following characteristics:

Firstly, the counting base of origin trade statistic is "customs area", which can only measure the opening degree of foreign trade of the country frontier than distinguish the participation degree of 
civil citizen and foreign citizen in the foreign trade of the country. While ownership trade based on the counting base that whether can transfer the commodity ownership among citizens of different countries, thus measure the participation degree of the citizen of the country to the foreign trade.

Secondly, the influence of foreign-owned enterprises and international production network on the economy and foreign trade of the country, including total trade volume, trade gap and trade structure, can be judged well by the comparison of origin trade statistics and ownership trade statistics.

Meanwhile, the comparison of the two factors can uncover how much trade unbalance of the country results in the civil citizen and foreign citizen well, thus reduce trade dispute.

However, it should be noted that ownership trade statistical system cannot replace current origin trade statistical system. The trade statistics based on origin principle is based on the customs management of goods and adapts to and is serviced by customs management. Moreover, foreign exchange and currency management are also based on frontier. Customs management has the same management and statistics with foreign exchange. The gap between ownership trade statistics system and customs statistics reflected more information of international trade, so ownership trade statistical system can be the necessary supplement of origin statistics.

\subsection{Practices that based on ownership statistical framework of current account of the US}

Because the US realized the defect of current trade statistical system firstly, so it has begun to collect the operation data of overseas subsidiaries since 1950s. National Academy of Sciences (1989) NAS that supplement the defect of current trade statistical system based on the trade statistical framework of ownership, which includes sales revenue of overseas subsidiary of the US; the principle is according to the ownership of asset, thus established clear relation between FDI and trade. NAS divided trade gap of the US into three parts: transnational import and export, foreign net marketing of foreign subsidiary body of the US and net marketing of foreign companies in the US. But it doesn't abandon traditional trade statistical system at the same time, but takes the statistical system based on ownership as supplement account of current account based on traditional trade statistical framework.

BEA has begun compiled current account based on ownership since 1992. BEA (2004) proposed that establish ownership statistical system, the compiled principle called BEA, which refers to decide state party by the right of trading object. This system includes the sales of overseas subsidiaries, which excluded double counting to a large extent; it is more perfect and scientific than traditional system.

\subsection{The comparison of trade statistical system based on ownership and cross-border trade statistical system}

Compared with cross-border trade statistical system, the most significant feature of trade statistical system based on ownership provided more information based on ownership, it is the supplement of cross-border trade statistical system.

Firstly, the trade statistics based on ownership divide cross-border trade into intra-trade of cross-border Company and non-affiliated company trade. While cross-border trade doesn't involve whether there is affiliated relation between importer and exporter. 
Secondly, compared with origin trade statistical system, the trade statistical system based on ownership added relative details of acquiring investing benefits of cross-border parent company from its overseas subsidiary companies, uncovered the net earnings of foreign directly investment of parent company by the item of "the net earnings of foreign directly investment of the US parent company from the sales of subsidiary companies".

Thirdly, compared with origin trade statistical system, the trade statistical system based on ownership introduced the concept of trade revenue gap that is the sum of traditional trade balance and net earnings of direct investment of the US. In this regard, the gap of net earnings (export of the US) of US parent company between cross-border import of the US and net expense of the US on foreign subsidiary companies in the US should be added into cross-border export and overseas subsidiary company sales of the US. This gap was listed as "the gap of commodity and service, as well as net sales revenue from subsidiary company" in the remarks. As the cross-border trade, it shows that cross-border company's sale product and service by subsidiary company is also the important method of participating international business activities.

Fourthly, the appendix of trade statistical system based on ownership provided respective shares of the US and foreign countries among the gross sales output (include inventory change: deduct sales of else subsidiary company which from one parent company) of subsidiary company. For example, the US shares of foreign countries in the US was also subdivided into two parts: the value added of the subsidiary company of the US itself, the value added of other US companies that put into middle elements; while cross-border trade statistical system has not provided this information.

\subsection{Counting method analysis based on ownership trade statistical system of the US from 2005 to 2007}

The statement that was called as "An Ownership-based Frame Work of the US Current Account" analyzed different margin of current accounts, variation of commodity and service trade, as well as cross-border trade and revenue, trade of subsidiary company and non-affiliated company and the constitution of sales and output of subsidiary company.

Table 4. the Difference of Four International Business Activities in the United States Based on the Principle of Ownership Statistics. Unit: \$100 million.

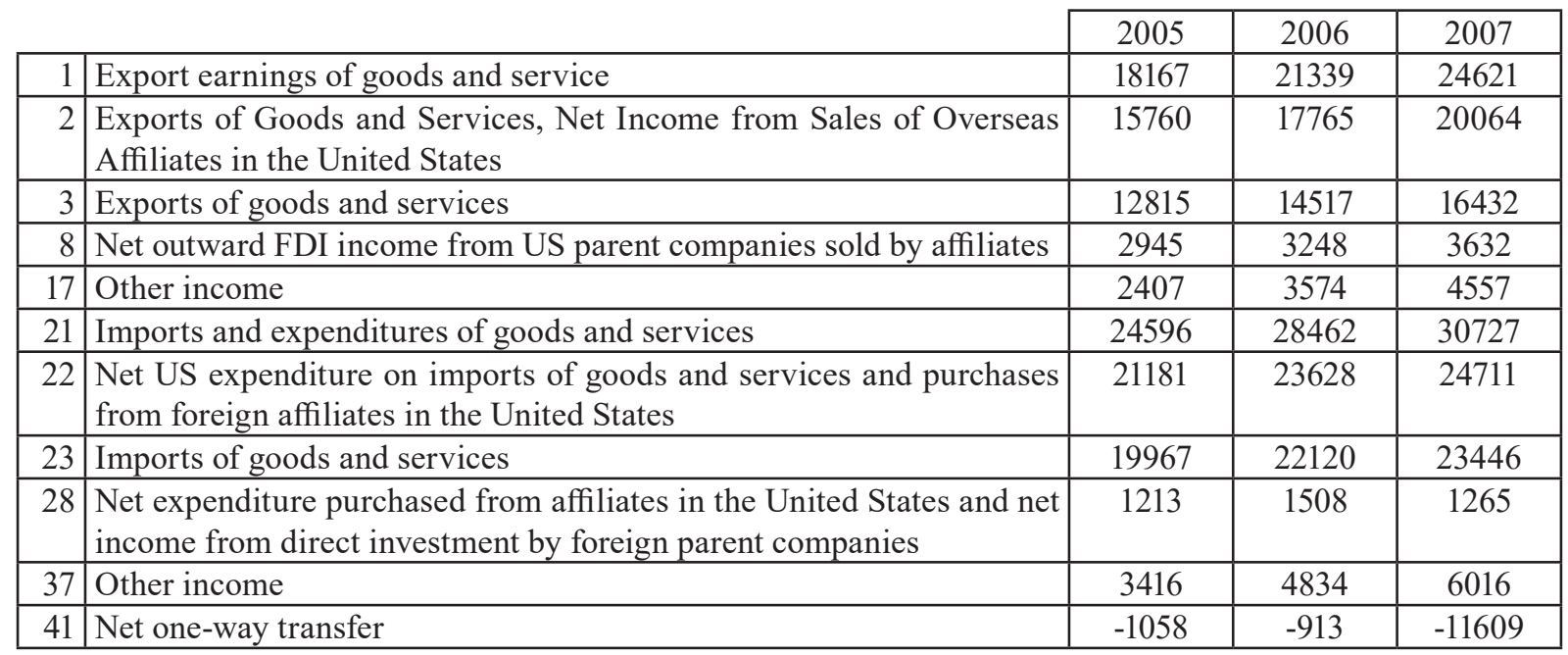

Source: Jeffery H. Lowe. (2012). An Ownership-based Frame Work of the US Current Account 1999-2008. 
According to the above table, ownership trade statistical system is as same as cross-border trade statistical system in the highest classify, which was divided into three categories: export earnings of commodity and service, import of commodity and service, as well as net unilateral transfer. The difference with cross-border trade statistical system is in the second category. Export of commodity and service was divided into three categories: export of commodity and service, net sales revenue of overseas subsidiary company of the US, as well as other earnings. Cross-border trade was subdivided into subsidiary company trade and not-affiliated company trade among them, while subsidiary company trade was further divided into the trade between parent company and its overseas subsidiary institutions of the US, as well as the trade of foreign subsidiary companies in the US and the foreign parent company. Net sales revenue of overseas subsidiary companies of the US was counted by non-bank subsidiary company and bank subsidiary company respectively.

According to the specific data, the first type is traditional gap of the balance of international payments. It is equal to the first line (export and revenue of commodity and service) minus the $21^{\text {st }}$ line (import and expense of commodity and service) plus the 41th line (net unilateral transfer). According to the data of Table, the margin of the current account of the US in 2005 is -748.7 billion dollars and -8036 billion dollars in 2006 .

The second type is trade gap of commodity and service; it is equal to the third line (export of commodity and service) minus the $23^{\text {rd }}$ line (import of commodity and service) of the graph. According to the data of Table, the trade gap of commodity and service of the US in 2007 is -7001.4 billion dollars.

The third type is a new gap come up from the statistical principle based on ownership, which was called as "the gap of commodity and service, as well as net sales revenue from subsidiary company", its computational formula is that the second line (commodity and service export, as well as net sales revenue from overseas subsidiary company of the US) minus the $22^{\text {nd }}$ line (commodity and service import, as well as the US net expense purchased subsidiary company in the US) of Table 4. According to Table 4, this gap of the US in 2007 is -464.7 billion dollars.

The forth type gap is also a new gap come up from statistical principle based on ownership, that is "the gap of foreign net investment revenue and net expense", its computational formula is that the $8^{\text {th }}$ line (foreign directly net investment revenue of the US parent company from subsidiary company sales) minus the $28^{\text {th }}$ line (net expense of subsidiary company in the US) of Table 4. According to Table 4, this gap of the US in 2007 is 236.7 billion dollars. The current trade statistical system cannot reflect the fourth gap, while it reflected the benefits of the US acquired by participating international business activities, which has practical significance. The trade statistical system based on origin rule cannot reflect the profit of transnational corporation acquired by subsidiary institutions sales correctly, so it doesn't really reflect the practical gains relation when a country participating international business activity. Under the trade statistical system based on ownership, the $8^{\text {th }}$ line (foreign directly net investment revenue of the US parent company from subsidiary company sales) of the graph records the net revenue of overseas subsidiary institutions of the US transnational parent company acquired from foreign business activity, that is sales revenue of overseas subsidiary institution minus the commodity and service of the subsidiary institution directly purchased from the US, minus the cost and profits (such as reward payment of subsidiary employees) that should be recorded in other countries, then minus sales revenue of others subsidiary institutions of the same US parent company. 
According to Table 4, the net revenue of overseas subsidiary institutions of the US in 2007 is 363.2 billion dollars. Meanwhile, the $28^{\text {th }}$ line (net expense of subsidiary company in the US) of Table 4 records the net investment revenue of the subsidiary institutions of foreign parent company in the US acquired by business activities in the US. It is equal to the sales revenue of subsidiary institutions of foreign parent company in the US minus the commodity and service of subsidiary company in the US directly purchased in overseas, then minus the cost and profits that should be recorded in the US (such as the rewards of the subsidiary employees in the US), then minus the sales revenue of other subsidiary companies in the US that come from the same parent company. According to Table 4, the net expense of the US in the subsidiary company in the US in 2007 is 126.5 billion dollars. The gap of the two items constituted "the gap of foreign net investment revenue and net expense".

Following results can be concluded by Table 4:

Firstly, transnational company distribute service and commodity by setting overseas subsidiary company; this form replaced traditional transnational trade, and the sales of these subsidiary institutions are even greater than transnational export scale. Import and export trade in transnational company occupied about $1 / 3$ of the foreign trade of the US. In 2003, the commodity export scale of the US is 723.8 billion dollars, while the sales of foreign subsidiary institutions reach up to 3383 billion dollars unexpectedly, almost 5 times of its export scale. Therefore, the main form of the US participate international business activity is the foreign subsidiary institution that formed by foreign directly investment, while participate international business by export and import is just a small part of foreign economic activity, and the US acquired huge benefits by the business activity of foreign subsidiary institution, while these benefits cannot be counted under the current income and expenditure statistical system. The foreign subsidiary institutions of the US acquired about 230 billion dollars in 2004, while the trade deficit the US counted is 535.7 billion dollars, which is nearly $1 / 2$ of the trade gap. The net benefits of the US are 129.3 billion dollars when excluded 100.5 billion dollars benefits those companies of other countries acquired by the subsidiary institutions in the US. While these 129.3 billion dollars reflected the actual gains of the US that participate in international business activity, however, the current trade statistical system exaggerated the trade deficit of the US because of omitting the huge gains of the US.

Secondly, the reason that foreign net directly investment revenue brings in trade balance is similar to transnational trade that transnational companies sell commodity and service to international market by subsidiary company. Including the US trade deficit of foreign net directly investment revenue will shrink $20 \%$ at least.

\section{CONCLUSION AND POLICY RECOMMENDATIONS}

Processing trade takes a large part in Sino-US trade, more than 55\% export of China to the US belong to processing trade at present, the raw materials, parts and package it needed are imported from Japan, Korea and Singapore, as well as Hong Kong and Taiwan, so China can only obtain few processing charges in processing trade. However, the whole value of the commodity was counted as imported from China in the US statistics, thus exaggerated trade deficit to China.

In addition, price rising of middleman also result in that the value of the US import declaration is higher than China's export declaration. However, both China and the US have not enough 
information to eliminate the influence of processing trade on Sino-US trade in trade statistics, because firstly, processing trade and carrying trade are crossed; secondly, the directly traded commodity that purchased and carried by middleman cannot be recognized; thirdly, it is hard to calculate the value-added part of China, that is the value-added proportion of labor intensive product and technology intensive product which are different. Therefore, it is hard to exclude the influence of processing trade on Sino-US bilateral trade statistics in Sino-US trade statistics.

China and the US need to negotiate and coordinate center on bilateral trade statistics. Under the precondition that both parts are reluctant to adjust current customs statistical system and rules, China and the US could establish a work team that adjust impartially statistical error caused by different customs statistical rules to let both parts reach a consensus on the severity awareness of Sino-US trade unbalance, thus the discussion can really center on substantial issues behind trade unbalance. Meanwhile, China should refer to the methods of Japan, Canada and Korea at the right moment to put forward bilateral trade coordination system to the US that coordinate the trade statistical number that specially coordinate the two countries.

In order to reflect the gains of China when joining international business activity more reasonably and scientifically and change the harmful situation of current trade statistical system brings to China, the trade statistical system based on ownership was established as supplement; the followings are suggestions:

Firstly, China should set up micro database that reflect business operation of foreign investing enterprises; they not only include the business activities of foreign enterprises in China, but also include Chinese "going out" foreign directly investment enterprises. At present, the data related to foreign-funded enterprises in China's Ministry of Commerce are relatively macroscopic, such as the countries that foreign capital investment flowed, but it not includes the micro situation data about foreign-funded enterprises that do business activities in China. However, the relative database must be established to set up a trade statistical system based on ownership, and constantly enrich and complete it.

Secondly, on the one hand, China need to set up and enrich the micro data of foreign-funded business activities; on the other hand, China should not give up "cross-border" trade accounting system based on origin rule for cross-border trade statistical system that is still the sole criterion when governments measure trade gains relations.

\section{REFERENCES}

[1] Huaiqin Jia. (2004). A Summary of Sino-US Trade Balance Issues, University of International Business and Economics Press in china.P16-19

[2] Huaiqin Jia. (1992). Comparability of Rules of Origin and Foreign Trade Statistics, International Trade Issues, No. 11, P9-21

[3] Xiangshuo Yin. (2001) International Trade Course, Fudan University Press, P26-30

[4] Xiaochao Li. (2008). China Statistical Yearbook, China Statistical Publishing House, P721-723

[5] Jeffery H. Lowe. (2012). An Ownership-based Frame Work of the US Current Account 1999-2008. 